\title{
História de uma experiência singular de ensino - Parte I: a criação do Curso de Física, Licenciatura, noturno, da UFBA ${ }^{+*}$
}

\author{
José Fernando Moura Rocha ${ }^{1,2}$ \\ Instituto de Física - Universidade Federal da Bahia \\ Salvador $-\mathrm{Ba}$
}

\section{Resumo}

O Curso de Física, Licenciatura, noturno, da Universidade Federal da Bahia (UFBA), implantado em 1999, trouxe em sua estrutura curricular algumas inovações importantes, entre as quais a criação das disciplinas Físicas Básicas I, II, III e IV. O nosso propósito, neste trabalho, é relatar o processo de criação e desenvolvimento desse curso, discutindo suas inovações curriculares, com atenção especial para o papel desempenhado pelas mencionadas disciplinas, desde a sua criação.

Palavras-chave: Curso de Física; Ensino de Física; História do ensino de Física.

\begin{abstract}
The night Physics Program for students who seek a teaching degree at the Federal University of Bahia (UFBA), introduced in 1999, brought in its curriculum some important innovations, including the creation of the disciplines Basic Physics I, II, III and IV. Our purpose in this paper is to describe the process of creation and development of this course, discussing its curricular innovations, with special attention to the role of the aforementioned disciplines, since its inception.
\end{abstract}

\footnotetext{
${ }^{+}$The story of a singular teaching experience - Part I: the creation of the nocturnal Physics degree course at the UFBA

* Recebido: dezembro de 2015.

Aceito: janeiro de 2015.

${ }^{1}$ Este trabalho estava sendo redigido por dois autores, os Profs. José Fernando Moura Rocha e Aurino Ribeiro Filho. Infelizmente, o Prof. Ribeiro Filho faleceu no dia 27 de agosto de 2015, e aqui lhe prestamos, mais uma vez, as nossas homenagens.

2 E-mail: josefernandomourarocha@gmail.com
} 
Keywords: Physics program; Physics teaching; History of Physics teaching.

\section{Introdução}

O objetivo deste trabalho é narrar o processo de criação e desenvolvimento do Curso de Física, Licenciatura, noturno, da Universidade Federal da Bahia, discutindo as inovações trazidas pela sua matriz curricular. A escolha deste tema foi motivada pela rica experiência propiciada por este curso de graduação, impulsionada por inovações que, entre outros aspectos importantes, incluía a criação de quatro novas disciplinas, denominadas Físicas Básicas I, II, III e IVª , que são oferecidas paralelamente às tradicionais Físicas Gerais e Experimentais, destinadas aos alunos da área de ciências exatas, inclusive aos alunos de Licenciatura em Física.

Para se entender as razões que levaram à criação do Curso de Física, Licenciatura, noturno, em 1998 (com implantação em 1999), descreveremos, a seguir, o quadro de carências na área de Física, particularmente na área de ensino de Física, no Brasil e na Bahia, àquela época. Deve-se salientar, inicialmente, que o processo de discussão que levou à criação desse curso foi iniciado em 1996, ano em que também foi promulgada a nova Lei de Diretrizes e Bases da Educação Nacional - LDBEN (Lei 9.394, de 23 de dezembro de 1996), que depois se revelou, indiretamente, um reforço na consolidação do mencionado curso noturno. Esta lei, como se sabe, trouxe a exigência de formação em nível superior, em cursos de licenciatura, de graduação plena, para todos os professores da Educação Básica ${ }^{4}$. A amplitude desta exigência foi avaliada, no ano seguinte, através de um censo realizado pelo Instituto Nacional de Estudos e Pesquisas Educacionais Anísio Teixeira - INEP, denominado "Censo do Professor", em âmbito nacional, cujos indicadores mostraram que um grande esforço deveria ser feito para atender às novas exigências legais. Alguns resultados deste censo, que alcançou mais de $90 \%$ da categoria, merecem destaque (BRASIL, 2012a):

1) dos 1.617.611 docentes da Educação Básica, no Brasil, pelo menos 823.655 tinham escolaridade que não ultrapassava o nível médio (cerca de 13\% destes eram docentes da rede privada). Na Bahia, em particular, dos 112.957 docentes da Educação Básica, pelo menos 91.778 tinham escolaridade que não ultrapassava o nível médio;

\footnotetext{
${ }^{3}$ As Físicas Básicas, apesar da denominação, não devem ser identificadas com os livros didáticos do Professor H. Moysés Nussenzveig, intitulados "Curso de Física Básica” (vols. 1, 2, 3 e 4).

${ }^{4}$ Lei 9.394/96, Art. 62. . : “A formação de docentes para atuar na educação básica far-se-á em nível superior, em curso de licenciatura, de graduação plena, em universidades e institutos superiores de educação, admitida, como formação mínima para o exercício do magistério na educação infantil e nas quatro primeiras séries do ensino fundamental, a oferecida em nível médio, na modalidade Normal". Prazos longos também foram estabelecidos, como por exemplo, no parágrafo 4..$^{\circ}$ do Art. 87. ${ }^{\circ}$ (Das Disposições Transitórias): “Até o fim da Década da Educação [iniciada em 23 de dezembro de 1997, um ano depois da publicação dessa Lei] somente serão admitidos professores habilitados em nível superior ou formados por treinamento em serviço" (SAVIANI, 1997), o que significa dizer que todo o pessoal docente deverá ter curso superior.
} 
2) dos 238.589 docentes atuando no ensino médio, no Brasil, pelo menos 24.672 tinham escolaridade que não ultrapassava o nível médio, sendo que, na Bahia, especificamente, dos 10.526 docentes atuando neste nível de ensino, pelos menos 3.707 tinham escolaridade que não ultrapassava o nível médio.

Em 2003, sete anos após a aprovação da LDBEN, outro levantamento de dados realizado pelo Instituto Nacional de Estudos e Pesquisas Educacionais Anísio Teixeira (BRASIL, 2012b) mostrou que, no caso específico da disciplina Física, dos 31.175 profissionais do magistério da Educação Básica que a ministravam, no Brasil (13,8\% atuando na rede privada), somente 3.095 tinham graduação em Física (cerca de 30\% destes atuando na rede privada) e 2.822 profissionais não eram sequer graduados. No caso da Bahia, dos 2.216 profissionais do magistério da Educação Básica que ministravam a disciplina Física, somente 89 eram diplomados em Física (cerca de $24 \%$ destes atuando na rede privada) e 711 não eram graduados. Os demais tinham curso de graduação concluído com a seguinte distribuição: 261 diplomados em Matemática; 279 na “Área 1"; 116 em Pedagogia/Ciências da Educação; 313 em outros cursos de graduação e 447 não informaram 5 .

O Censo de 2003 mostrou ainda que, na Bahia, dos 2.216 profissionais do magistério da Educação Básica com grau de formação superior, que ministravam a disciplina Física, apenas 1.090 tinham licenciatura, sendo que 415 não tinham licenciatura alguma e os demais não tinham grau de formação superior (619) ou não informaram (92).

Dentre os dados apresentados, merece atenção especial o fato de que, dos 2.216 profissionais da Educação Básica que ministravam a disciplina Física, somente 89 eram diplomados em Física (Licenciatura ou Bacharelado). Considerando que a disciplina Física é ministrada, geralmente, a alunos do ensino médio, pode-se concluir que, neste nível de ensino, em 2003, na Bahia, a carência de professores licenciados em Física era de mais de 2.000 profissionais. Este era e ainda é um quadro desolador, tendo em vista que entre 1997 e 2011 foram licenciados, no Estado da Bahia, apenas 821 profissionais, sendo 596 licenciados e 225 bacharéis (ROCHA, 2014), e a maioria não se mostrava interessada em ministrar aulas nas escolas de nível médio.

Apesar da importância desses dados estatísticos para formar uma ideia precisa dos problemas relacionados às deficiências do ensino no Brasil e, particularmente, na Bahia, deve ser esclarecido que na época em que o Colegiado do Curso de Graduação em Física iniciou as discussões (1996), visando ao aperfeiçoamento do seu curso de graduação, não era necessário qualquer exercício de estatística para se perceber que a carência de professores de ensino médio, público e privado, no Estado da Bahia, particularmente na área de Física, não vinha sendo suprida, satisfatoriamente, pelos cursos regulares de formação de professores licenciados. Esse

\footnotetext{
${ }^{5}$ Para efeito de comparação com o Estado de São Paulo, o mais desenvolvido economicamente do país, estes números eram os seguintes: dos 7.876 profissionais do magistério da Educação Básica que ministravam a disciplina Física, somente 809 eram diplomados em Física (cerca de 40\% destes atuando na rede privada) e 314 não eram graduados. Os demais tinham curso de graduação concluído com a seguinte distribuição: 3.159 diplomados em Matemática; 1.814 na “Área 1”; 560 em Pedagogia/Ciências da Educação; 220 em outros cursos de graduação e 1.000 não informaram. Havia seis vezes mais graduados em Matemática e "Área1" que graduados em Física, ensinando Física, pelo mesmo salário.
} 
quadro não mudou muito mesmo após a promulgação da LDBEN, em que pese a soma do número de vagas para o vestibular de Física, nas universidades baianas, ter aumentado de 50 para 250 entre 1997 e $2006^{6}$. Este é o número que se obtém ao se somar as vagas oferecidas pela Universidade Federal da Bahia, Universidade Estadual de Feira de Santana (UEFS), Universidade Estadual de Santa Cruz (UESC), Universidade Estadual do Sudoeste da Bahia (UESB) e Universidade Federal do Recôncavo (UFRB), até 20067. A UEFS passou a oferecer 30 vagas em Física, a partir do início de 1997, com a criação da Licenciatura, tendo esse número aumentado para 40 vagas, a partir de 1999, com a criação também do Bacharelado em Física. Por sua vez, a UESC passou a oferecer 10 vagas, a partir de 1999 (hoje, 20 vagas), com a criação do Curso de Física, Licenciatura, noturno, e mais 10 vagas, a partir de 2001 (hoje 20 vagas), com a criação do Bacharelado em Física, diurno, e a UESB passou a oferecer 40 vagas, a partir de 2001, com a criação da Licenciatura em Física, enquanto a UFBA aumentou sua oferta de 50 para 90 vagas, em Salvador, a partir do início de 1999, sendo as 40 novas vagas oferecidas pelo Curso de Física, Licenciatura, noturno. Por fim, o número total de vagas passou para 250, em 2006, com a criação de mais 40 vagas pela UFRB, campus de Amargosa ${ }^{8}$.

A ideia da criação do Curso de Física, Licenciatura, noturno, na UFBA surgiu nesse contexto da mais absoluta falta de professores de Física para atuar, especialmente, no ensino médio, em que a carência, historicamente, tem sido parcialmente suprida por estudantes universitários dos mais variados cursos e por outros profissionais. Essa carência revelava-se ainda mais preocupante quando considerados os índices de evasão do Curso de Física, diurno, da UFBA, que, no período de 1971 e 1995, ficavam em torno de $78 \%$ (dos 1.357 alunos ingressos nesse período, 1.065 evadiram-se). Se tomarmos em conta apenas o período de 1972 a 1988 , este índice é ainda maior, conforme se pode ver na Fig. 1.

\footnotetext{
${ }^{6}$ De 1997 a 2011 foram licenciados em Física, na Bahia, 596 professores, sendo 261 pela UFBA, 98 pela UEFS, 98 pela UESC, 126 pela UESB e 13 pela UFRB - Campus de Amargosa (ROCHA, 2014).

${ }^{7}$ O Curso de Física do Campus de Barreiras - UFBA foi implantado somente em 2009. O Curso de Física, Licenciatura, do Instituto Federal de Educação, Ciências e Tecnologia - IFBA, teve início em 2011, e o Curso de Física, Licenciatura, do Campus de Itapetinga da UESB, foi implantado em 2012.

8 Até 1996, o Curso de Física, Licenciatura e Bacharelado, diurno, da UFBA era o único do Estado da Bahia. Na UESC, até 1998, havia um Curso de Ciências, Licenciatura Plena, com habilitações em Química, Física, Matemática e Biologia, autorizado a funcionar em 06 de novembro de 1980. Na UESB, havia um Curso de Ciências, Licenciatura Curta, com habilitações em Física e Matemática, que começou a ser oferecido em 1982 e entrou em processo de extinção em 1998.
} 


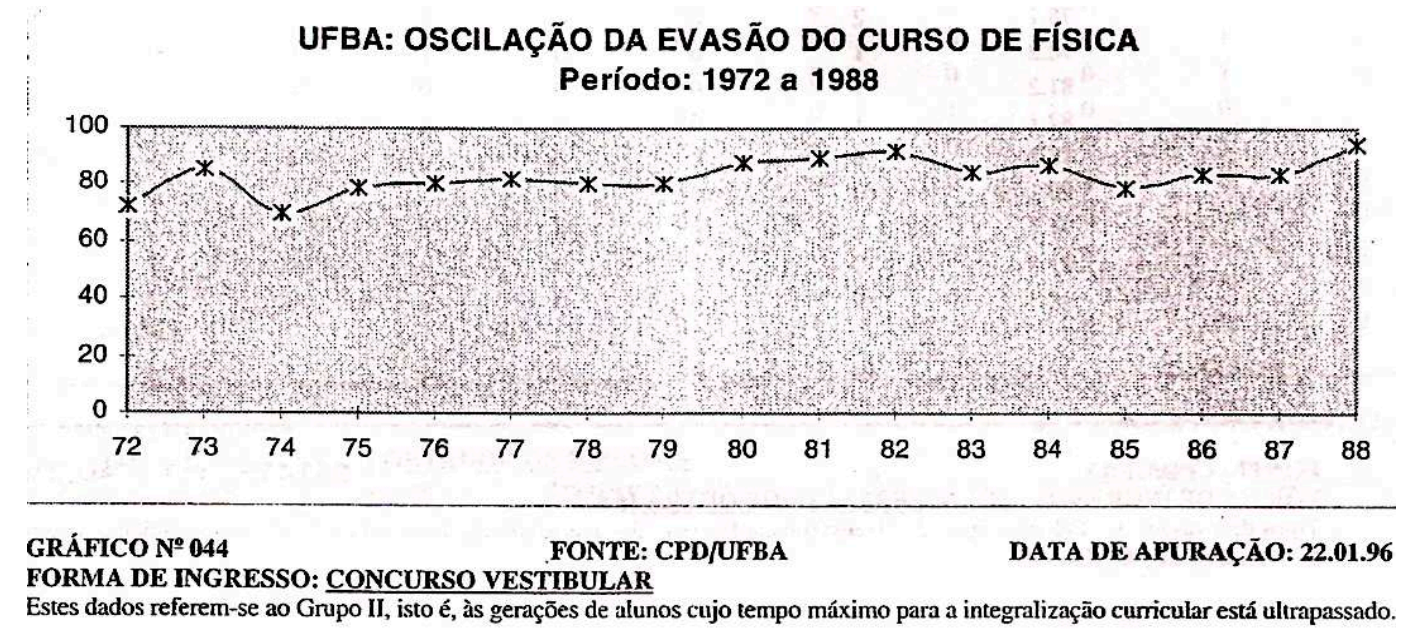

Fig. 1 - Oscilação da evasão do curso de física no período de 1972 a 1988.

Fonte: Araújo (1996).

Foi em razão desse quadro de desmotivação que o Colegiado do Curso de Física, da UFBA passou a buscar as causas da origem dos problemas vividos pelo mencionado Curso de Física, diurno, bem como identificar propostas para solucioná-los. A proposta de criação do Curso de Física, Licenciatura, noturno, surgiu com o objetivo de alterar este quadro.

Embora o citado Colegiado reconhecesse a necessidade de um estudo mais aprofundado para identificar as causas do desinteresse dos jovens, pelo curso de Física, havia certo consenso que tal desinteresse era devido, principalmente, aos baixos salários pagos aos profissionais do ensino médio e à reduzida oferta de trabalho para o Bacharel. Mas isso não era tudo. Apesar de estes serem considerados os fatores principais, outros relacionados à estrutura e organização acadêmica da própria UFBA podiam, também, ser, facilmente, identificados como a desatualização curricular e a inadequação dos horários de funcionamento dos cursos, ou melhor, de oferecimento das disciplinas. Nessa época eram oferecidas disciplinas somente durante o dia, em horários variados, ocupando, às vezes, parte do período da manhã e, outras vezes, parte do período da tarde, dificultando a matrícula daqueles alunos que eventualmente precisassem trabalhar.

A inadequação dos horários de funcionamento dos cursos foi melhor compreendida a partir de uma pesquisa realizada pelo mencionado Colegiado com alunos de Física, no início de 1998, em que ficou evidenciada a exigência de alteração no quadro de oferta de disciplinas, em razão do perfil dos alunos de Física, àquela época, e do fato de tais disciplinas só serem oferecidas no período diurno. A pesquisa revelou que dos 64 alunos que fizeram a pré-inscrição para o primeiro semestre de 1998 (de um total de 148 alunos matriculados), 58\% trabalhavam e apenas 6\% deles preferiam aulas no turno vespertino (IFUFBA, 1998).

Este resultado mostrava claramente que os alunos que trabalhavam tinham de conciliar seus horários de trabalho com a matrícula em disciplinas oferecidas apenas durante o dia, o que 
certamente não era uma tarefa fácil. Apesar de significativa, esta amostragem era limitada, pois não alcançou os alunos que já tinham abandonado o curso ou não se matricularam naquele semestre.

Tendo em conta que a solução de parte dos problemas vividos pelo Curso de Física estava no âmbito da própria universidade, o Instituto de Física, através de seu Colegiado do Curso de Graduação, resolveu buscar soluções, especialmente, para aqueles problemas que lhes diziam respeito diretamente: a inadequação dos horários de funcionamento dos cursos e a desatualização curricular. No processo de discussão, iniciado em 1996, logo se verificou que os recursos humanos existentes não viabilizariam a criação simultânea da Licenciatura e do Bacharelado noturnos. Considerada esta evidência, o Instituto de Física encaminhou aos órgãos superiores da UFBA, a criação do Curso de Física, Licenciatura, noturno, ficando o Bacharelado para uma outra oportunidade 9 .

Este novo curso de Licenciatura trouxe em sua estrutura algumas inovações importantes, entre as quais a criação das denominadas Físicas Básicas I, II, III e IV. O nosso propósito, neste trabalho, conforme referido, é relatar o processo de criação e desenvolvimento do Curso de Física, Licenciatura, noturno, da Universidade Federal da Bahia, discutindo as inovações curriculares do mencionado curso, com atenção especial para o papel desempenhado pelas citadas disciplinas, conforme será apresentado na Parte II deste trabalho.

\section{O novo Curso de Física, Licenciatura, noturno, da UFBA}

\section{II.1 Um pouco de história}

Até o início da década de 1990, a maioria das universidades federais não oferecia cursos noturnos de licenciatura em ciências e matemática. A partir de 1992, entretanto, este quadro começou a mudar e, em 1995, os ventos da mudança alcançaram a UFBA. Isto é o que pode ser depreendido ao se ler o Projeto Pedagógico do Curso de Física, Licenciatura, noturno, aprovado pela Câmara de Ensino de Graduação da UFBA, em sessão de 14 de maio de 1998. De acordo com o texto do Projeto (IFUFBA, 1998):

A partir de 1992, iniciou-se um processo intensivo de implantação de cursos noturnos de licenciatura em ciências e matemática nas universidades federais. Neste período diversos projetos foram elaborados e implementados: UFRJ,

\footnotetext{
${ }^{9}$ A graduação em Física, na UFBA, na cidade de Salvador, se apresenta, hoje, em dois cursos: o Curso de Física, diurno, que possui as modalidades Licenciatura e Bacharelado, e o Curso de Física, noturno, que possui apenas a modalidade Licenciatura. A Resolução n. ${ }^{\circ}$ 2, de 1. ${ }^{\circ}$ julho de 2008, do Conselho de Ensino, Pesquisa e Extensão da UFBA, que "Estabelece definições, princípios, modalidades, critérios e padrões para a organização dos cursos de graduação da UFBA", classifica a Licenciatura e o Bacharelado como sendo modalidades de cursos de graduação. No seu Art. 9. ${ }^{\circ}$, por exemplo, diz que "Quando um mesmo curso oferecer as modalidades bacharelado e licenciatura o ingresso será único". É comum, entretanto, o uso da denominação "Curso de Licenciatura em Física" para designar a modalidade Licenciatura em Física. Esta designação é usada, por exemplo, na Resolução n. ${ }^{\circ}$ 9, do Conselho Nacional de Educação, de 11 de Março de 2002, que "Estabelece as Diretrizes Curriculares para os cursos de Bacharelado e Licenciatura em Física”.
} 
UFPe, UFMG, UFG, UFMT, UFRPe, UFSM/RS, UnB, etc. ${ }^{10}$ Em 1995, foi criado, na UFBa, por iniciativa da Pró-Reitoria de Graduação, o Fórum de Licenciaturas, composto pelos representantes dos diversos cursos de licenciatura, com o objetivo de discutir o aperfeiçoamento dos 17 cursos hoje existentes, todos oferecidos no período diurno e alguns com elevadíssimos índices de evasão, os quais não são, entretanto, um fenômeno apenas da UFBa.

Motivado por essas discussões iniciais e incentivado pela promulgação da nova Lei de Diretrizes e Base da Educação Brasileira (Lei n. ${ }^{\circ}$ 9.394/96, de dezembro de 1996), que estabelecia a obrigatoriedade de diploma de Licenciatura também para o professor de ensino básico, o Colegiado do Curso de Física da UFBA, diurno, sob a orientação de novo Coordenador, desde dezembro de 1995, resolveu ampliar os debates internos no Instituto de Física e incluir na pauta de discussão a reformulação do Curso de Física, diurno.

No período de discussões, foi convidado o professor Antônio Carlos Pedrosa, da Universidade de Brasília - um dos responsáveis pela implantação dos cursos noturnos da UnB para realizar, no Instituto de Física da UFBA, um seminário com o tema "Cursos Noturnos", incentivando a discussão sobre a estrutura curricular que deveria ter o futuro Curso de Física, noturno, a ser, eventualmente, implantado na UFBA. Logo se constatou que a dificuldade de contratação de novos professores indicava ser inviável a criação simultânea do Bacharelado e da Licenciatura noturnos. As atenções se dirigiram então para a criação apenas da Licenciatura, turno noturno, com a eventual ampliação das vagas para o Curso de Física, diurno, o que exigiria uma oferta menor de disciplinas profissionalizantes à noite e, portanto, reduziria a exigência de contratação de novos professores. Em maio de 1997, na 196. ${ }^{\text {a }}$ reunião do Colegiado do Curso de Graduação em Física (diurno), foi aprovada, formalmente, a ideia de criação do Curso de Física, Licenciatura, noturno, com 40 vagas anuais, e, também, a ideia da ampliação de 50 para 80 vagas para o Curso de Física, diurno, com entrada semestral de 40 alunos, ampliação esta também aprovada pela Congregação do Instituto de Física da UFBA, mas que, até 2012, não tinha sido viabilizada. Após várias discussões realizadas durante o ano de 1997, em 30 de março de 1998, o Colegiado do Curso de Física apresentou ao Diretor do Instituto de Física, professor Manuel Blanco Martinez, para ser submetido aos órgãos superiores do Instituto de Física e da Universidade, o Projeto Pedagógico do Curso de Física, Licenciatura, a funcionar no período da noite. Em 15 de maio de 1998, a Câmara de Ensino de Graduação da UFBA aprovou o projeto, autorizando o funcionamento do Curso de Física, Licenciatura, noturno, através do Parecer 116/98.

Durante o ano de 1999, o Curso de Física, Licenciatura, noturno, ficou sob a responsabilidade do Colegiado do Curso de Física, diurno, mas, em razão das demandas próprias do período noturno, em 14 de dezembro de 1999 foi criado um colegiado específico para o Curso

\footnotetext{
10 UFRJ, Universidade Federal do Rio de Janeiro; UFPE, Universidade Federal de Pernambuco; UFMG, Universidade Federal de Minas Gerais; UFG, Universidade Federal de Goiás; UFMT, Universidade Federal de Mato Grosso, UFRPe, Universidade Federal Rural de Pernambuco; UFSM/RS, Universidade Federal de Santa Maria no Rio Grande do Sul e UnB, Universidade de Brasília.
} 
de Física, Licenciatura, noturno. Em 2012, os cursos diurno e noturno de Graduação em Física voltaram a ter um único colegiado.

\section{II.2 A criação do novo Curso}

Desde o início das discussões (1996), a ideia que norteava as ações do Colegiado era a de que o Curso de Física, Licenciatura, noturno, na hipótese de sua criação, não deveria ser diferente, em sua essência, daquele já ministrado no período diurno. Os objetivos, conteúdos curriculares etc. deveriam ser os mesmos e as diferenças deveriam residir apenas nas adaptações necessárias ao período noturno para adequá-lo às especificidades de sua clientela que, em grande parte, desempenhava tarefas profissionais, não podendo dedicar-se em tempo integral à Universidade. Certamente, isto é o que teria sido feito se o currículo da Licenciatura em Física, diurno estivesse atualizado, porém este não estava. Poder-se-ia pensar que o primeiro passo seria atualizá-lo e, em seguida, adequá-lo ao período da noite. Esta opção, entretanto, não se mostrava viável, pois, naquela oportunidade, as estruturas curriculares da Licenciatura e do Bacharelado diurnos ainda possuíam um forte núcleo comum, remanescentes do chamado modelo curricular 3+1, de origem francesa. Mas como já se compreendia que, de imediato, não seria possível criar, simultaneamente, a Licenciatura e o Bacharelado, noturnos, a opção escolhida foi a de se buscar apenas uma proposta de currículo para a Licenciatura em Física, noturno, e, oportunamente, estendê-la para o curso diurno. Esta ideia tinha a vantagem de deixar o Colegiado com mais liberdade de introduzir inovações na estrutura curricular da nova Licenciatura, o que de fato aconteceu.

Uma dessas inovações foi a criação de um maior número de disciplinas específicas profissionalizantes e de formação básica para os estudantes de Licenciatura. No que concerne ao nível básico da Licenciatura, a criação das citadas disciplinas Físicas Básicas I, II, III e IV, ao lado das tradicionais Físicas Gerais e Experimentais (I, II, III e IV), introduziu, de modo efetivo, uma desejada articulação entre História da Ciência (História da Física), aspectos filosóficos da Ciência e experimentos de laboratório, em um curso de preparação de professores. Estas disciplinas, juntamente com outras do chamado grupo profissionalizante, passaram a caracterizar o núcleo específico do Curso de Licenciatura, noturno. Tal inovação, aparentemente sem maiores consequências, era uma ruptura importante com as concepções dominantes entre os professores que ensinavam Física na UFBA, em sua maioria com formação em Física pura (bacharéis, mestres ou doutores), geralmente não muito atentos às estratégias metodológicas e aos recursos pedagógicos que norteiam ou que deveriam nortear o ensino, como processo de construção e produção do conhecimento.

É importante notar que, até a implantação do Curso de Física, Licenciatura noturno, em 1999, a discussão sobre a necessidade de uma reformulação curricular do curso de Física não conseguia ultrapassar a questão: valorização do conteúdo versus valorização do método (ou da "forma"), como se fossem contraditórios. O problema relevante de qual conteúdo ensinar em cada etapa de formação do licenciando não era devidamente considerado. Isto, certamente, 
era e ainda é uma limitação do que realmente importa na formação de um professor de física. De acordo com a concepção, expressa nas matrizes curriculares anteriores à criação da Licenciatura noturna, os alunos de licenciatura deveriam ser instruídos ou treinados nas mesmas disciplinas do Bacharelado e, ao seu final, cursar algumas disciplinas de caráter pedagógico (envolvendo fundamentos de psicologia, didática, metodologia etc.), para terem direito ao grau de Licenciado em Física. Levada até as últimas consequências, esta concepção dava origem a distorções e um exemplo marcante era a obrigatoriedade dos alunos da Licenciatura em Física, diurno, cursarem disciplinas típicas de um Bacharelado em Física, tal como Mecânica Geral e Teórica I e II (90 horas semestrais cada uma; efetivamente 102 horas), ao tempo em que era mantida como opcional a disciplina sobre a Teoria da Relatividade Restrita. Era e é, pois, flagrante a insensibilidade para a importância que tiveram e continuam tendo as mudanças conceituais introduzidas pela Teoria da Relatividade Restrita. Esta, vale esclarecer, também não é obrigatória para o Bacharelado, ao menos até o ano 2012.

Por outro lado, a inexistência de uma disciplina profissionalizante sobre o Eletromagnetismo, de caráter obrigatório, destinada aos alunos da Licenciatura, diurna, era mais uma forte evidência que confirmava a distorção existente na matriz curricular da Licenciatura, diurna, ao menos até 2012, orientada pela concepção já referida. Estas distorções causaram prejuízos aos licenciados e, consequentemente, à sociedade. Tais distorções, apesar de não serem o único fator, nem o fator principal, também contribuíram para o baixíssimo número de licenciados egressos do Instituto de Física da UFBA, que não passou de 150 licenciados até 1998 (ROCHA, 2014). Esta parece ter sido a contribuição involuntária da Universidade para o não fortalecimento do ensino de Física no Estado da Bahia, determinado pela política educacional governamental de pouca valorização às ciências.

\section{II.3 O novo currículo do Curso}

A seguir serão apresentadas as principais inovações trazidas pelo currículo da Licenciatura noturna, tomando como referência o currículo da Licenciatura, diurna.

Com a finalidade de adaptar o curso à sua clientela, o tempo médio do Curso de Física, Licenciatura, noturno, foi concebido para 5 anos, em lugar dos 4 anos estabelecidos para o curso diurno. Além disso, foi elaborada uma grade curricular que pudesse ser cumprida, levando-se em conta uma carga horária diária relativamente pequena, especialmente nos quatro primeiros semestres, quando não passaria de 16 horas semanais. A cadeia de pré-requisitos não impedia que, com um maior número de horas semanais distribuídas, nos turnos diurno e noturno, as mesmas disciplinas do currículo noturno fossem cursadas em 8 semestres.

Visando maior flexibilidade e, ao mesmo tempo, tendo em conta que parte da clientela necessitaria de uma ampliação desses conteúdos dentro de uma nova visão da Física, diferente daquela, geralmente, adotada no ensino médio, os tópicos das disciplinas até então oferecidas para o curso diurno de graduação em Física (FIS125-Física Geral e Experimental I-F, FIS126- 
Física G. e Experimental II-F, FIS127-Física G. e Experimental III-F e FIS128-Física G. e Experimental IV-F, com carga horária de 150 horas cada uma, ou 170 horas efetivas), foram redistribuídos em dois grupos de quatro disciplinas. No primeiro grupo, estavam as disciplinas FIS121-Física Geral e Experimental I-E, FIS122-Física Geral e Experimental II-E, FIS123Física Geral e Experimental III-E e FIS124-Física Geral e Experimental IV-E, com carga horária de 90 horas semestrais (102 horas efetivas), sendo todas obrigatórias, com 60 horas teóricas e 30 experimentais. No segundo grupo, estavam as chamadas Física Básicas (Física Básica I, II, III e IV), destinadas a explorar enfaticamente os aspectos históricos, fenomenológicos (experimentais) e conceituais dos conteúdos básicos de Física, sem esquecer os aspectos matemáticos, com 60 horas semestrais cada (30 teóricas e 30 experimentais), sendo as duas primeiras obrigatórias e as duas últimas optativas.

Quanto às disciplinas de Física, referentes ao ciclo ou nível profissionalizante, levando-se em conta que os licenciados devem ter uma formação profissional mais aprofundada que a oferecida pelas físicas iniciais, foram criadas três: Complementos de Mecânica (em substituição às disciplinas Mecânica Geral e Teórica I e II), Complementos de Termodinâmica (em substituição à Termodinâmica) e Complementos de Eletromagnetismo. No que diz respeito aos conteúdos de física moderna, do ciclo profissionalizante, foi mantida a disciplina FIS101-Estrutura da Matéria I, como obrigatória e a FIS102-Estrutura da Matéria II foi transformada em complementar optativa para os alunos do citado curso. Foram também introduzidas como optativas, as disciplinas: Complementos de Física Moderna, Introdução à Física Matemática e uma quarta disciplina de cálculo, denominada, àquela época, MAT007-Cálculo IV. As duas primeiras eram disciplinas novas. No que diz respeito à FIS112-Evolução da Física, do ciclo profissionalizante, optativa para os cursos diurnos, esta passou a ser obrigatória para a Licenciatura noturna. Para introduzir o estudante no uso de recursos computacionais, enfatizando o seu enorme potencial de aplicação ao ensino, foi incluída, à época, uma nova disciplina, denominada Informática Aplicada à Física e foram transformadas em complementares optativas as disciplinas MAT045-Processamento de Dados e MAT174-Cálculo Numérico.

No que diz respeito às disciplinas da área de Educação, foram introduzidas novas disciplinas como complementares optativas. A relação das disciplinas obrigatórias e complementares optativas pode ser examinada ao final, junto com o fluxograma do curso (vide Anexos 1 e 2).

Das disciplinas citadas, dois conjuntos merecem comentários especiais: as chamadas Físicas Básicas e os chamados Complementos de Mecânica, de Termodinâmica e de Eletromagnetismo. Convém observar, por exemplo, o caso de Complementos de Mecânica, uma disciplina com 5 horas de aula semanais. Da mesma forma que Complementos de Eletromagnetismo e de Termodinâmica, a mencionada disciplina era considerada pelo Colegiado de Curso indispensável à boa formação dos licenciados em Física. O Colegiado entendia que nessas disciplinas dever-se-ia enfatizar temas diretamente relacionados ao ensino da Física, devendo-se ir além de um simples treino matemático, procurando a essência dos conceitos e alcançando 
seus limites. A denominação "Complementos de Mecânica" e a carga horária eram pouco ambiciosos, mas tinham o propósito de transmitir a ideia de que a "Mecânica" ministrada aos licenciados deveria ser equivalente e não igual àquela Mecânica ministrada aos bacharéis. Este mesmo raciocínio deveria ser estendido aos Complementos de Termodinâmica e aos Complementos do Eletromagnetismo. A criação de disciplinas profissionalizantes específicas para os licenciados, abordando respectivamente conteúdos de Mecânica, Termodinâmica e Eletromagnetismo parece ter sido um dos acertos da proposta do currículo do curso noturno de Licenciatura em Física, instalado em 1999, pois a recente proposta de reformulação curricular mantém essas disciplinas como obrigatórias no novo currículo de Licenciatura.

\section{II.4 O novo Curso de Física nos seus primeiros anos}

Ainda no mês em maio de 1998, logo após a aprovação pela Câmara de Ensino de Graduação do projeto de criação do Curso de Física, Licenciatura, noturno, foi iniciada a sua divulgação através das mais variadas formas. Além daquela padrão feita pelos órgãos da administração central da Universidade, o Instituto de Física da UFBA tomou a iniciativa de também divulgar a criação do novo curso, enviando cartazes às escolas de ensino médio de Salvador, textos explicativos das condições oferecidas para o funcionamento do mesmo curso, e ainda cumpriu uma programação de visitas às principais escolas, da qual participou também o Diretor do Instituto de Física, Manuel Blanco Martinez, visitando inclusive emissoras de rádio, a exemplo da Radio Excelsior da Bahia, existente (ainda hoje) no Bairro do Garcia, onde deu entrevista ao vivo ${ }^{11}$.

A grande divulgação realizada, reforçada pela novidade da proposta, produziu resultados imediatos. Já no primeiro semestre de 1999, com o ingresso da primeira turma de 40 alunos, foi possível verificar o acerto da iniciativa. Nos anos que se seguiram, consolidou-se a certeza de que este curso era plenamente viável, apesar das dificuldades naturais advindas do não funcionamento regular da Universidade no período da noite. O primeiro grande desafio superado nesse período foi o de encontrar professores para todas as disciplinas do curso, especialmente as de Matemática. Presteza não faltou aos Departamentos de Matemática, de Química, de Educação I, de Educação II e naturalmente aos Departamentos do Instituto de Física da UFBA para atender as demandas do Colegiado do Curso de Física, Licenciatura, noturno. Aquele era, entretanto, um período de grandes dificuldades e, muitas vezes, foi difícil encontrar até mesmo Professor Substituto que aceitasse ministrar determinadas disciplinas no período da noite. Um caso emblemático foi o de um professor (Professor Substituto) de Cálculo III que faltou por um período longo e, em seguida, simplesmente desistiu de ministrar a disciplina por ter conseguido emprego em uma universidade particular, problema que, felizmente, foi contornado pelo Chefe

\footnotetext{
11 Aliás, esta não foi a primeira vez que iniciativas desta natureza tinham sido tomadas. Na década de 1960, esforços com objetivos de despertar o interesse dos jovens para ingressar no Curso de Física tinham sido feitos, primeiro, pelo professor Waldez Alves da Cunha (por volta de 1962) e, mais tarde, independentemente, por outros professores.
} 
do Departamento de Matemática. Outro fato não menos representativo das condições da época, foi a dificuldade deste Departamento em encontrar um Professor Substituto para ministrar a disciplina Cálculo II, já que, simplesmente, não apareciam candidatos. Diante da ameaça dos alunos ficarem sem cursar esta disciplina naquele semestre, o Colegiado de Física desenvolveu gestões para convencer a professora Nice Maria Americano da Costa Costa Pinto, do Instituto de Física, a ministrá-la, o que de fato foi feito com a ajuda da professora Elinalva Vergasta de Vasconcelos, do Instituto de Matemática, que, mesmo sobrecarregada, aceitou ministrar as aulas de exercício da citada disciplina. É justo também aqui ressaltar o comprometimento dos Departamentos de Matemática, de Química Inorgânica, de Educação I e II e dos Departamentos do Instituto de Física que, na época da criação do Curso de Física, Licenciatura, noturno, compreendendo a importância social do projeto, concordaram em oferecer as disciplinas obrigatórias, mesmo sem a garantia de novos concursos.

Por outro lado, a concentração das aulas apenas no prédio do Instituto de Física (e, eventualmente, na Faculdade de Educação) reduzia o problema de segurança em razão da pouca movimentação de pessoas no Campus de Ondina. Da parte da Direção do Instituto de Física não faltaram esforços para suprir as demandas do curso, inclusive abrindo sua Biblioteca à noite e munindo-a também com alguns livros de Matemática, cedidos temporariamente pelo Instituto de Matemática.

Após cinco anos de funcionamento, em 2003, procedeu-se a uma avaliação mais detalhada do desempenho do curso, constatando-se que, de fato, este havia sido uma experiência muito bem sucedida, desfazendo as dúvidas que ainda poderiam pairar quanto a sua viabilidade, por continuar sendo o único curso noturno da UFBA até aquela data, situação que perdurou até 200712 .

A primeira constatação foi a de que, com a criação do Curso de Física, Licenciatura, noturno, o número de interessados no Curso de Física, diurno, aumentou significativamente de 1998 para 1999 (vide Tabela 1). A relação candidatos-vaga no vestibular referente ao ano de 1999 aumentou em relação ao ano de 1998, mesmo com o aumento do número de vagas oferecidas para os cursos de Física, em razão da criação de 40 vagas para o Curso de Física, Licenciatura, noturno. Para os candidatos que desejaram ingressar no Curso de Física, diurno, no ano de 1998 (ano anterior à implantação do curso noturno), o Curso de Física, diurno, oferecia somente 50 vagas no vestibular e a relação candidatos-vaga foi de 1,98, ou seja, inscreveram-se 99 alunos. No ano seguinte, após o aumento de vagas para os cursos de Física, com a criação de 40 vagas no Curso de Física, Licenciatura, noturno, a concorrência para o curso diurno aumentou para 3,7 candidatos-vaga, perfazendo um total de 183 alunos inscritos e, simultaneamente, a concorrência para o recém-criado Curso de Física, Licenciatura, noturno, foi de 4,7 candidatos-vaga, com 186 alunos inscritos. Passando, portanto, de 99 alunos inscritos, no turno

\footnotetext{
12 Até 2010, o Curso de Física, Licenciatura, noturno, foi o único curso noturno a diplomar alunos pela UFBA: 123 alunos concluíram o curso até aquele ano. Em 2012, dos 112 cursos da UFBA (nos seus diversos campi), 34 eram de licenciatura. Dos 33 cursos noturnos da UFBA (sendo 31 em Salvador e 2 em Barreiras), 12 eram de licenciatura, dos quais $11 \mathrm{em}$ Salvador e 1 em Barreiras. (UFBA, 2012).
} 
diurno, em 1998, para 369 alunos inscritos (diurno e noturno) no ano de 1999. Um crescimento de quase 4 vezes. As relações candidatos-vaga nos anos seguintes mantiveram-se estáveis, sendo que no ano de 2002 foi de 4,1 (diurno) e de 5,1 (noturno), num total de 437 candidatos inscritos. A evolução da relação candidatos-vaga para o curso diurno, desde 1996, e para o curso noturno, desde 1999, podem ser vistas na Tabela 1 e no Gráfico 1, mostrados a seguir. No período de 1999 a 2009, a média das relações candidatos-vaga foi de 4 tanto para o curso diurno quanto para o noturno. A partir de 2010, entretanto, esta média passou para o patamar de 3 (diurno) e 2,5 (noturno).

TABELA 1 - Relação candidatos-vaga no Vestibular de Física - UFBA - período 1996-2012.

\begin{tabular}{|r|r|r|r|r|r|r|r|r|r|r|r|r|r|r|r|r|r|}
\hline Ano & $\mathbf{1 9 9 6}$ & $\mathbf{1 9 9 7}$ & $\mathbf{1 9 9 8}$ & $\mathbf{1 9 9 9}$ & $\mathbf{2 0 0 0}$ & $\mathbf{2 0 0 1}$ & $\mathbf{2 0 0 2}$ & $\mathbf{2 0 0 3}$ & $\mathbf{2 0 0 4}$ & $\mathbf{2 0 0 5}$ & $\mathbf{2 0 0 6}$ & $\mathbf{2 0 0 7}$ & $\mathbf{2 0 0 8}$ & $\mathbf{2 0 0 9}$ & $\mathbf{2 0 1 0}$ & $\mathbf{2 0 1 1}$ & $\mathbf{2 0 1 2}$ \\
\hline Física - diurno & 2,1 & 2,5 & 2,0 & 3,7 & 4,7 & 3,1 & 4,7 & 4,2 & 4,5 & 3,7 & 4,9 & 4,1 & 4,1 & 3,6 & 3,0 & 3,2 & 2,7 \\
\hline $\begin{array}{l}\text { Física Licencia- } \\
\text { tura - noturno }\end{array}$ & - & - & - & 4,7 & 4,8 & 3,7 & 5,1 & 4,4 & 3,7 & 4,3 & 3,8 & 5,1 & 3,3 & 4,0 & 2,3 & 3,4 & 1,8 \\
\hline
\end{tabular}

Fonte: Pró-Reitoria de Planejamento e Orçamento - Setor de Informação e Documentação. Evolução do Concurso Vestibular Física e Física Noturno, 1990-2012.

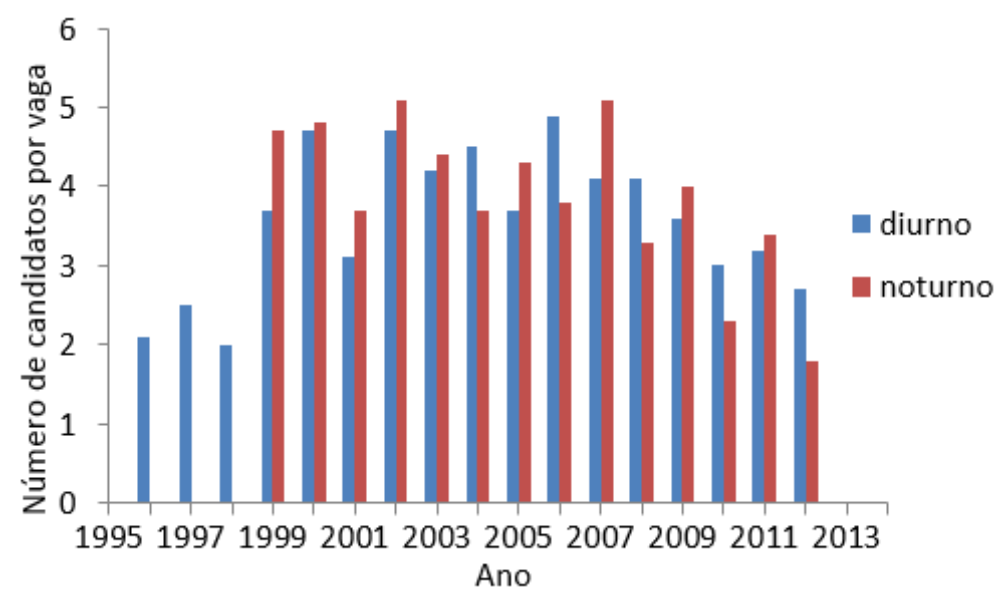

Gráfico 1 - Candidatos-vaga no vestibular de Física - UFBA - Salvador. O aumento do número de candidatos por vaga, no curso diurno, ocorreu apenas após a criação e implantação do Curso de Física, Licenciatura, noturno (1999), e não nos dois anos que se seguiram (1997 e 1998) à promulgação da nova Lei de Diretrizes e Bases da Educação Nacional (Lei 9.394, de 23 de dezembro de 1996). Fonte: Rocha (2014).

O sucesso não se mostrou somente no aumento da concorrência, mas também no número de alunos matriculados a cada ano. De acordo com Rocha (2014), em1998, ano anterior à implantação do Curso de Física, Licenciatura, noturno, o número de alunos matriculados, no primeiro semestre, na Licenciatura e no Bacharelado, diurnos, era de 165, mas, em 2003, no quinto ano de implantação do curso noturno, o total de alunos matriculados nos cursos diurno 
e noturno de Física, da UFBA, em Salvador, era de 392 alunos, sendo 221 diurnos e 171 noturnos (o curso de Física do Campus de Barreiras só foi implantado em 2009). No primeiro semestre de 2011, esse número era de 474 alunos em Salvador, sendo 298 diurnos e 176 noturnos (Em 2011, havia, formalmente, 19 alunos matriculados no Curso de Física, Campus de Barreira, da UFBA). No Gráfico 2, a seguir, obtido por Rocha (2014), pode-se observar o número de alunos matriculados no Curso de Física, diurno, no período de 1952 a 2011. A comparação entre o número de alunos matriculados nos cursos diurno e noturno pode ser vista no Gráfico 3. O Gráfico 4 mostra, ano a ano, o total do número de alunos matriculados nos cursos de Física, diurno e noturno, desde a criação de cada um deles.

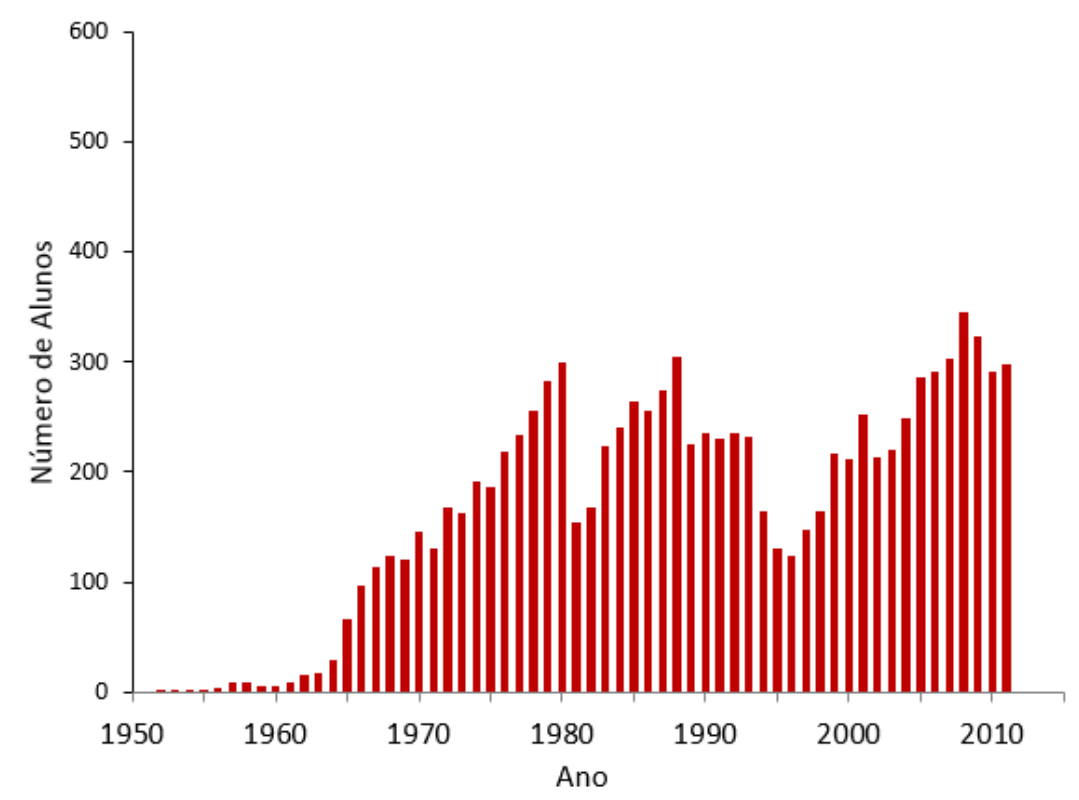

Gráfico 2 - Matrícula no Curso de Física - UFBA - Salvador - diurno. Fonte: Rocha (2014).

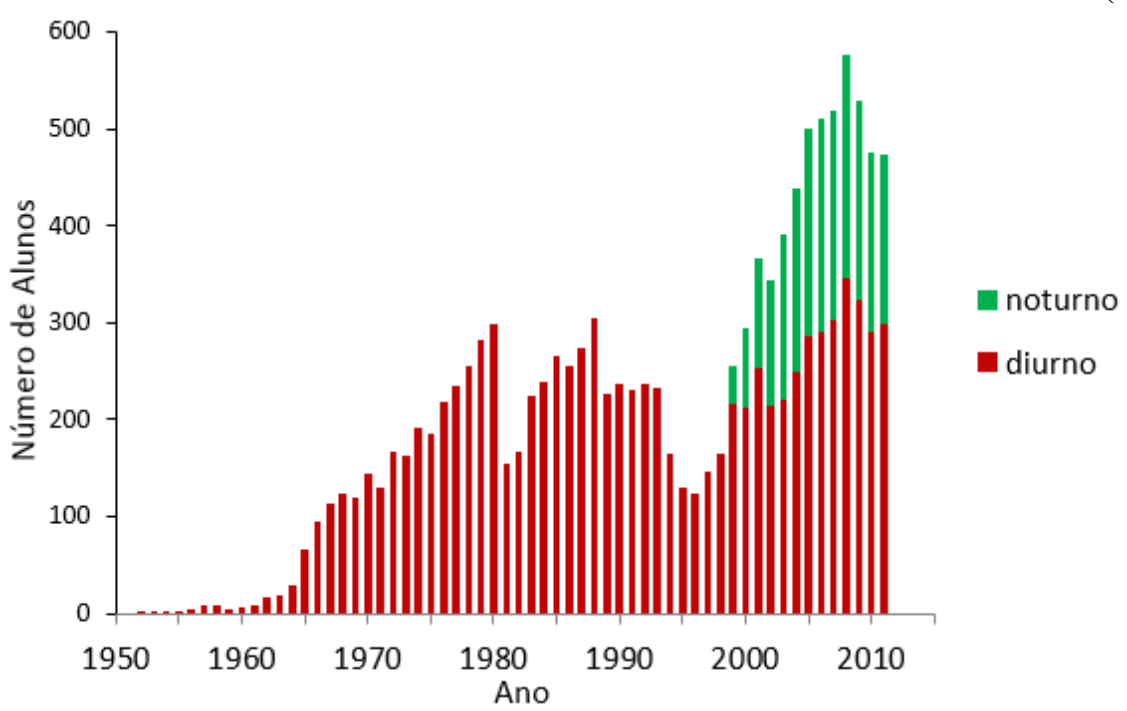

Gráfico 3 - Matrícula no Curso de Física - UFBA - Salvador - diurno e noturno. Fonte: Rocha (2014). 


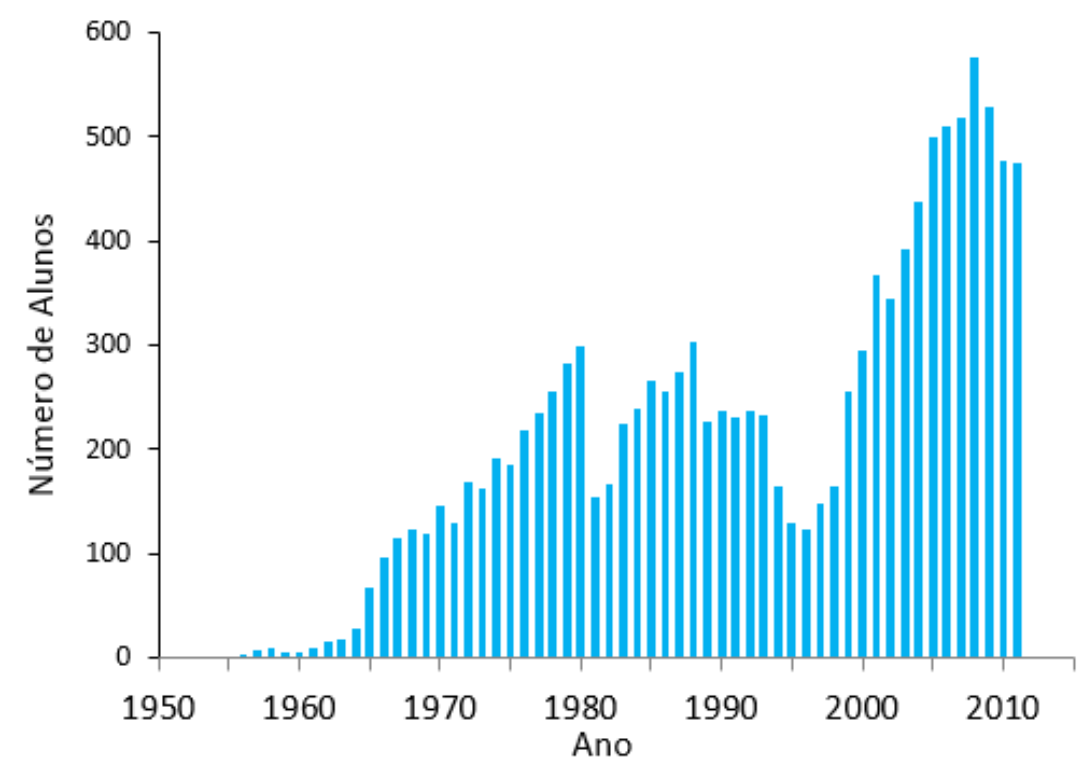

Gráfico 4 - Matrícula nos Cursos de Física - UFBA - Salvador - soma do diurno e noturno. Fonte: Rocha (2014).

Convém registrar que o sucesso maior não ficou por conta só do aumento do número de alunos matriculados nos cursos de Física. Foi verificado também um aumento significativo do número de alunos concluintes-ano, do Curso de Física, diurno, além do expressivo número de alunos concluintes-ano no Curso de Física, Licenciatura, noturno, o que pode ser observado nos Gráficos 5, 6 e 7 adiante, obtidos por Rocha (2014). Este é o resultado de um levantamento completo do número de alunos que colou grau desde 1955. O citado trabalho de Rocha (2014) mostra também que, até 2002, mesmo antes da formatura regular dos alunos do curso noturno, prevista para 2003, o Curso de Física, Licenciatura, noturno, já havia diplomado 10 alunos, o que ocorreu em razão de aproveitamento de estudos anteriormente realizados. A primeira turma regular de formandos colou grau, no segundo semestre de 2003, de modo que dos 40 alunos que ingressaram, em 1999, 20 (50\% - um número acima dos padrões históricos do Curso de Física da UFBA) colaram grau até 2003, isto é, no tempo médio previsto de cinco anos para o curso noturno.

No período de 1955 a 1968, foram diplomados pela UFBA cerca de 38 profissionais na área de Física, numa média aproximada de 3 concluintes por ano. Esta média subiu para 10 concluintes por ano, no período de 1969 a $1998^{13}$ e para 31 no período de 1999 a 2011, ou para 40 no período de 2003 a 2011, se considerado que a primeira turma regular de formandos do curso noturno foi diplomada em 2003 (ROCHA, 2014).

\footnotetext{
${ }^{13}$ Se fosse tomado como referência os dados do Arquivo Eletrônico do Setor de Informação e Documentação da Pró-Reitoria de Planejamento e Orçamento da UFBA e não aqueles observado no Livro de Registro de Diplomas do Setor de Diplomas, da Superintendência Acadêmica da UFBA, no período de 1955 a 1968 esta média seria de 3 ao ano, sendo que no período de 1969 a 1998 esta média subiria para 8 alunos ao ano, o que corresponde a 246 concluintes e não a 296, conforme Rocha (2014), que é o valor observado nos Livros de Registro de Diplomas, do Setor de Diplomas da UFBA. Os dados acadêmicos destas duas fontes não coincidem.
} 


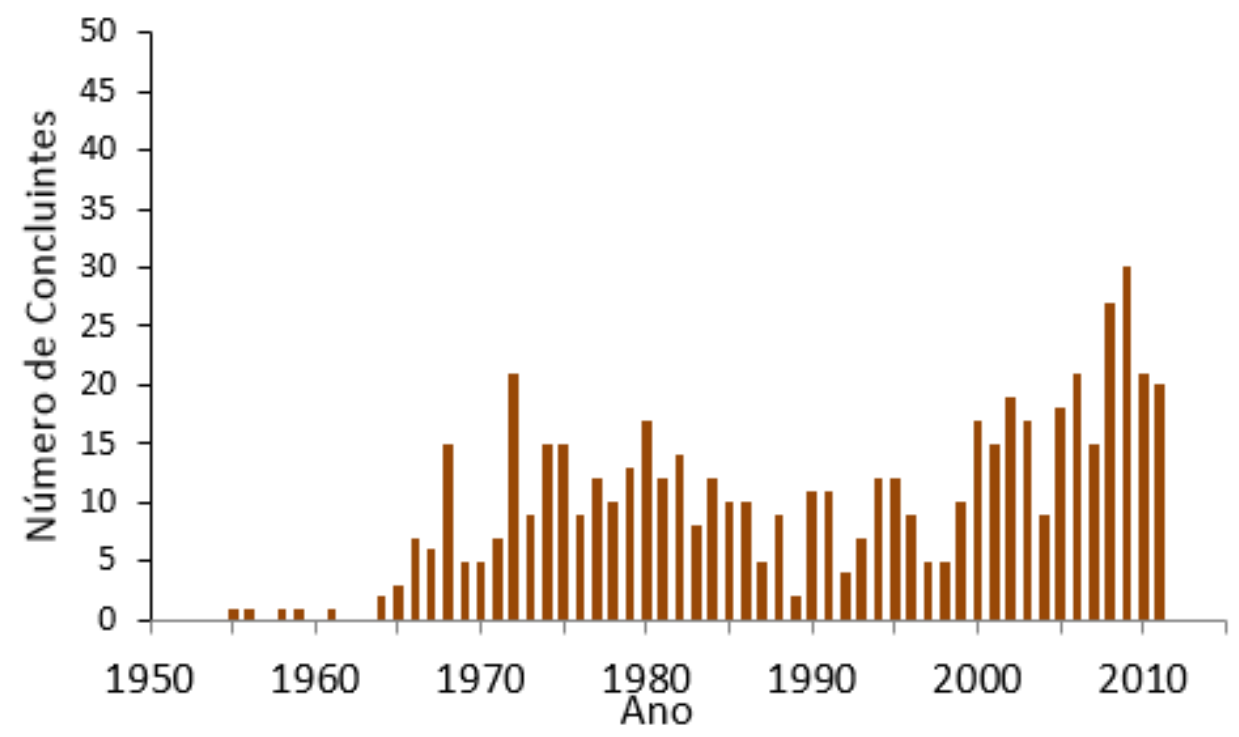

Gráfico 5 - Concluintes do Curso de Física - UFBA - Salvador - diurno. Fonte: Rocha (2014).

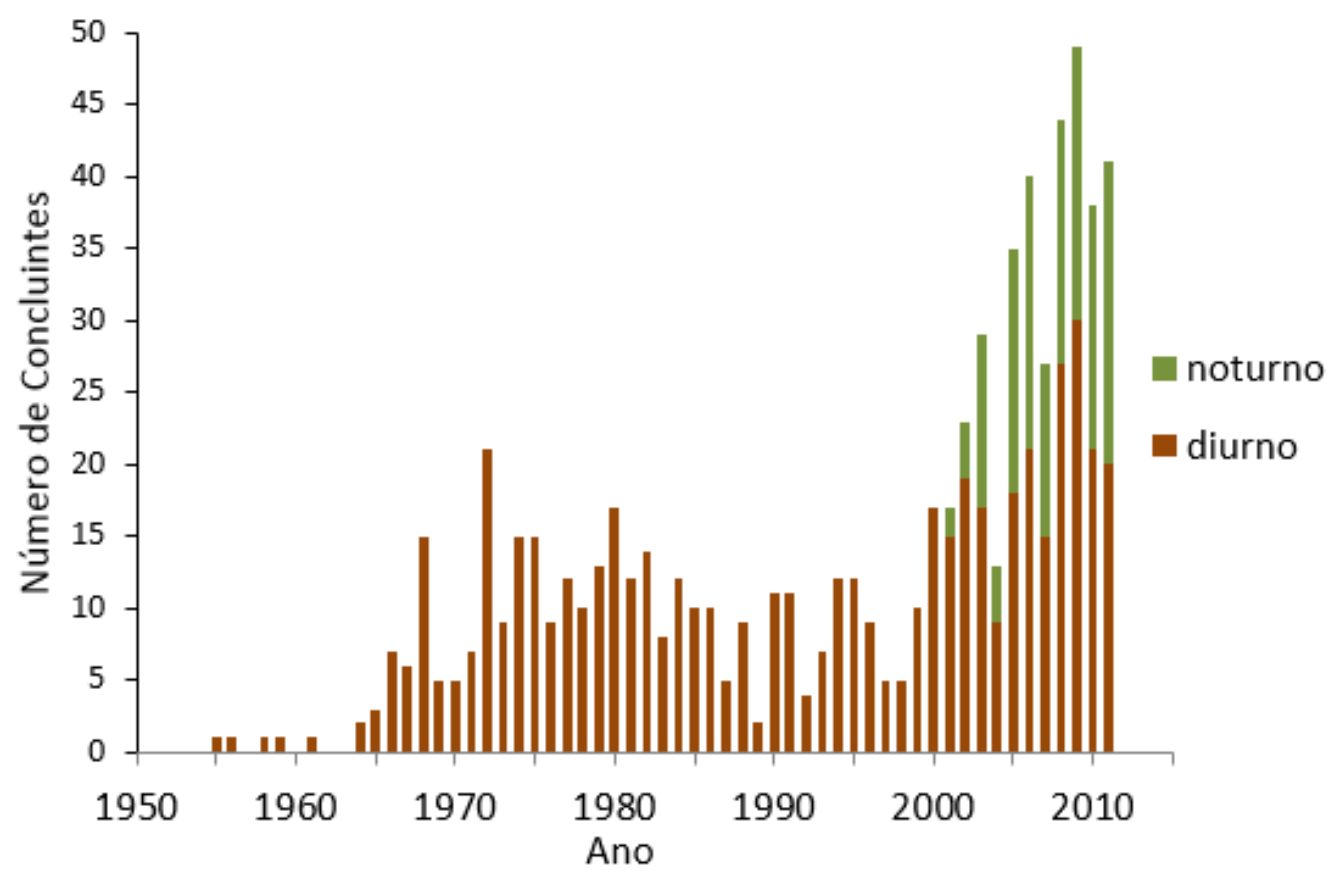

Gráfico 6 - Concluintes do Curso de Física - UFBA - Salvador - diurno e noturno. Fonte: Rocha (2014). 


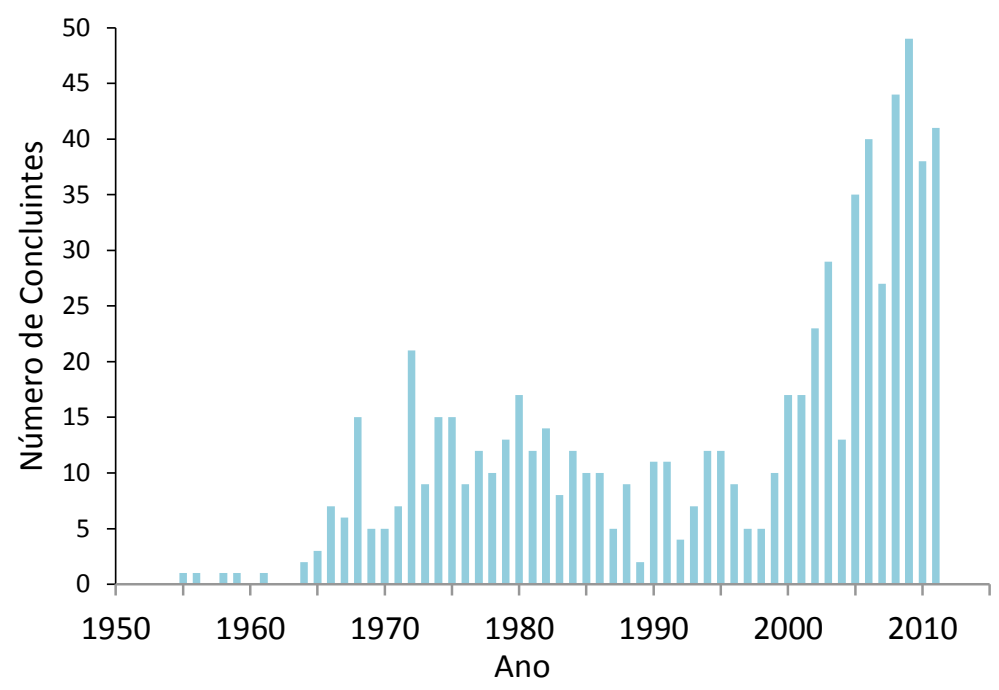

Gráfico 7 - Concluintes do Curso de Física - UFBA - Salvador - soma do diurno e noturno. Fonte: Rocha (2014).

Os resultados discutidos anteriormente permitem fazer algumas considerações importantes sobre a criação do Curso de Licenciatura, noturno, naquela oportunidade. A comparação dos Gráficos 2 e 5, por exemplo, revela que, por volta de 1996, o Curso de Física, diurno, da UFBA, (não só o Curso de Física, conforme será observado, adiante), passava por um processo de esvaziamento, o qual se caracterizava pela redução paulatina do número de alunos matriculados no Curso de Física, diurno, e pela simultânea diminuição do número de concluintes. Na época, este fato era percebido pelo Colegiado de Graduação através da facilidade com que se realizava a matrícula de cada semestre em razão do baixo comparecimento dos alunos e do reduzido número de concluintes em cada semestre, a ponto de, no primeiro semestre de 1997 , não haver sequer um concluinte e no segundo semestre desse mesmo ano, somente 3 licenciandos e 2 bacharéis terem sido diplomados. Este processo de esvaziamento por que passava o Curso de Física, diurno, pode ser melhor percebido se a análise do processo for concentrada

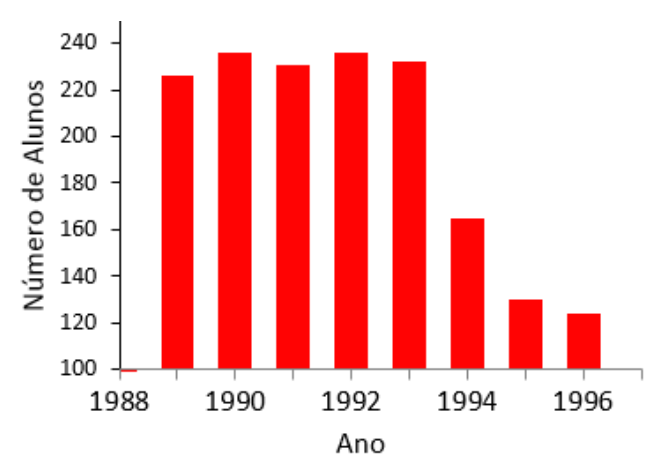

Gráfico 8 - Matrícula no Curso de Física - UFBA - Salvador - diurno. Fonte: Rocha (2014).

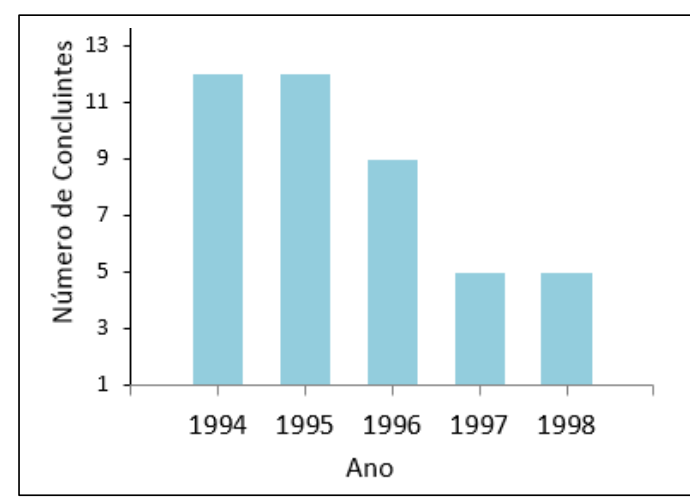

Gráfico 9- Concluintes do Curso de Física - UFBA- Salvador - diurno. Fonte: Rocha (2014). 
no período de 1989 a 1996, o que pode ser observado nos Gráficos 8 e 9. É de notar que, em meados da década de 1990, houve não só uma redução do número de concluintes como também do número de alunos matriculados no curso de Física, em período equivalente, o que não aconteceu em outros momentos de baixo número de diplomação, como aquele verificado no ano de 1989. O desligamento voluntário dos alunos, em meados da década de 1990, parecia desaconselhar a abertura de mais vagas para o curso de graduação em Física, da UFBA e, consequentemente, parecia não recomendar a criação de um novo Curso de Física, nesta Universidade ${ }^{14}$. A avaliação que se fazia, entretanto, era a de que havia um número elevado de potenciais candidatos, com poucos recursos financeiros, desejosos de realizar um curso superior o que não era possível por não existir, àquela época, universidade pública na Bahia oferecendo cursos noturnos. O esperado era que a proposta de criação de um Curso de Física, Licenciatura, noturno, atendesse pelo menos parte desta demanda.

Concluindo, deve-se registrar que o mencionado esvaziamento de cursos, em meados da década de 1990, referido anteriormente, não era uma particularidade do Curso de Física. O Gráfico 10 mostra que outros cursos passavam por um fenômeno semelhante, a exemplo do Curso de Química. Isto, entretanto, não era o que acontecia com todos os outros cursos de graduação da UFBA, a exemplo do Curso de Engenharia Química, pelo menos na intensidade que ocorreu com o de Física e o de Química. Uma análise aprofundada desse fenômeno merece um estudo específico, a ser realizado oportunamente.

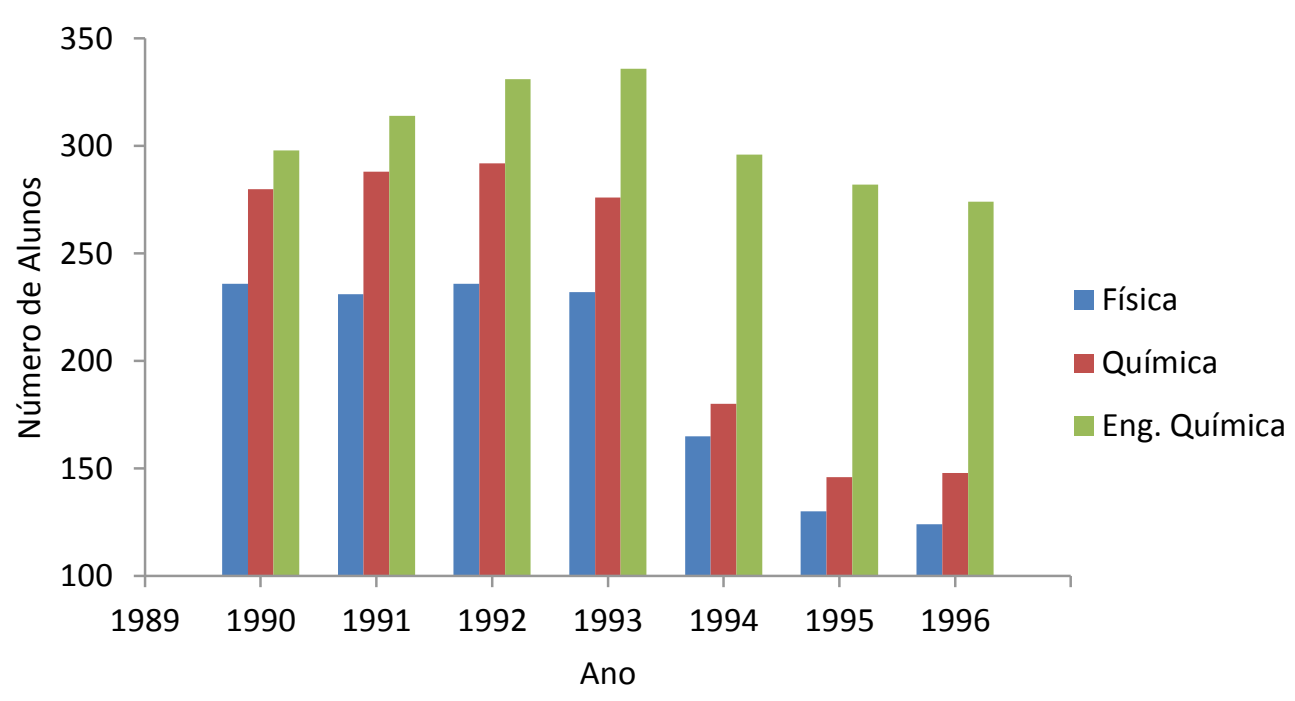

Gráfico 10 - Matrícula nos Cursos de Física, Química e Engenharia Química, diurnos - UFBA - Salvador. Fonte: Rocha (2014).

\footnotetext{
${ }^{14}$ A ideia de criação do Curso de Física, Licenciatura, noturno, foi aprovada pelo Colegiado de Física, diurno, em maio de 1997, na sua 196. ${ }^{a}$ Reunião.
} 


\section{II.5 Diplomação de alunos nas Universidades da Bahia no período 1997-2011}

A demanda por professores de Física ficou longe de ser suprida pelos concluintes dos cursos de Física diplomados pela UFBA e outras universidades da Bahia, no período 1997 2011. Neste intervalo de tempo, foram licenciados no Estado da Bahia 596 alunos, dos quais 144 eram licenciados pelo Curso de Física, Licenciatura, noturno, da UFBA, sendo que no período de 2003 a 2011 foram licenciados 548, quando a carência mostrada pelo "Censo dos Profissionais de Educação Básica 2003” era de mais de 2.000 profissionais, só no Estado da Bahia (ROCHA, 2014). Além disso, há de se ter em conta que houve expansão da rede escolar de ensino médio, o que manteve a carência em números superiores a 1.500 profissionais, supondo a não incorporação de licenciados formados em outros estados da Federação à rede pública baiana.

Outro resultado do "Censo dos Profissionais do Magistério da Educação Básica 2003”, relacionado também com o anterior, que merece ser destacado, é o fato de, em 2003, só haver cerca de 89 diplomados em Física (Licenciados ou Bacharéis) ensinando a disciplina Física nos colégios da Bahia. Se for considerado que, entre 1969 e 2002, somente o Instituto de Física da UFBA havia diplomado 168 licenciados e 189 bacharéis (num total de 357 profissionais), podese concluir que o problema não é só de carência de novos profissionais, mas também da existência de outros fatores que afastam parte dos novos profissionais das salas de aula, das redes pública e privada, de nível médio, dentre os quais, os baixos salários pagos aos professores. Muitos alunos licenciados em Física preferem continuar os estudos para adquirir o diploma de Bacharel e outros preferem desenvolver atividades diferentes daquelas próprias do ensino regular em escolas de nível médio.

\section{Conclusões}

Ao longo do texto, ficou evidenciado que a proposta de criação do Curso de Física, Licenciatura, noturno, decorreu da necessidade de dar resposta, no âmbito da universidade, aos problemas observados no Curso de Física da UFBA, diurno, por volta de 1996. Após mais de um ano de discussões no Colegiado de Graduação em Física, o Instituto de Física aprovou a proposta que estava ao alcance dos recursos humanos existentes para responder a pelo menos dois problemas básicos observados no seu Curso de Física, diurno: o da inadequação de horários de funcionamento e o da desatualização curricular. A proposta de currículo aprovada para o curso noturno, trouxe algumas inovações em comparação à matriz curricular do curso diurno e, entre estas inovações, destaca-se a criação das Físicas Básicas I, II, III e IV, e dos Complementos de Eletricidade, de Mecânica e de Termodinâmica, além de outras disciplinas, que não havia nos currículos da Licenciatura e do Bacharelado, diurnos. 
Os dados apresentados nesta primeira parte do trabalho revelam o quanto foi acertada a decisão de se criar o Curso de Física, Licenciatura, noturno, mesmo num período de esvaziamento por que passava o Curso de Física, diurno, em meados da década de 1990. Na Parte II, será apresentada a história da experiência singular de ensino realizada no Curso de Física, Licenciatura, noturno, da UFBA, envolvendo o conteúdo da física universitária básica, ministrado através das mencionadas Físicas Básicas, destinadas, especificamente, a alunos da Licenciatura em Física, e que são oferecidas, paralelamente, às tradicionais Físicas Gerais e Experimentais, destinadas aos alunos das engenharias, inclusive aos alunos da Licenciatura em Física, do curso noturno.

Concluímos, afirmando que o Curso de Física, Licenciatura, noturno, trouxe inúmeros benefícios à sociedade baiana, a partir da oferta de vagas a alunos impossibilitados de cursar Física no turno diurno, tendo permanecido, por oito anos, desde sua criação em 1998, como o único curso noturno da UFBA.

\section{Referências Bibliográficas}

ARAÚJO, R. P. C. de. et al. UFBa: O Ensino de Graduação em Debate. Salvador: Empresa Gráfica da Bahia, 1996.

BRASIL - INSTITUTO NACIONAL DE ESTUDOS E PESQUISAS EDUCACIONAIS INEP. Perfil do Magistério da Educação Básica - Censo do Professor 97. Disponível em: <http://portal.inep.gov.br/web/guest/basica-censo > . Acesso em: 27 jul. 2012a.

BRASIL - INSTITUTO NACIONAL DE ESTUDOS E PESQUISAS EDUCACIONAIS INEP. Sinopse do Censo dos Profissionais do Magistério da Educação Básica 2003. Disponível em: <http://portal.inep.gov.br/web/guest/basica-censo >. Acesso em: 27 jul. 2012b.

IFUFBA - INSTITUTO DE FÍSICA DA UFBA - Colegiado de Graduação em Física, Projeto Pedagógico Curso Noturno de Licenciatura em Física. Autorização para funcionamento aprovada pela Câmara de Ensino de Graduação em sessão de 14 de maio de 1998 - Parecer 116/1998.

NUSSENZVEIG, H. M. Curso de Física Básica - Mecânica. São Paulo: Edgard Blucher, v. $1,1998$.

ROCHA, J. F. M. Origens e Evolução do Curso de Física, Licenciatura, Noturno, da Universidade Federal da Bahia: O Caso das Disciplinas Físicas Básicas III e IV. Salvador: UFBA, 2014. 711 p. Tese (Doutorado) - Programa de Pós-Graduação em Ensino, Filosofia e História das Ciências. Universidade Federal da Bahia, Salvador, Bahia, 2014.

SAVIANI, D. A Nova Lei da Educação. Campinas: Editoras Autores Associados, 1997. 
UFBA - UNIVERSIDADE FEDERAL DA BAHIA. Pró-Reitoria de Planejamento e Orçamento. Setor de Informação e Documentação. Relação de Cursos da UFBA, em 2012, por Modalidade e Turno. 2012.

\section{Anexo 1 \\ Matriz curricular do (novo) Curso de Física - Licenciatura, noturno, para alunos ingres- sos no ano de 1999}

Área 1

- Currículo do Curso Notumo de Licenciatura em Física

o Licenciado em Física se ocupa em ministrar de maneira critica e fundamentada o conhecimento correspondente à Fisica - essencialmente à nivel médio -, da criação de novos recursos e melodologias de ensino e da análise dos processos de aprendizagem da Física.

BASE LEGAL - Parecer n 296/62, aprovado em 17.11.62 com Resolução anexa do C.F.E.

\section{Elenco de Disciplinas}

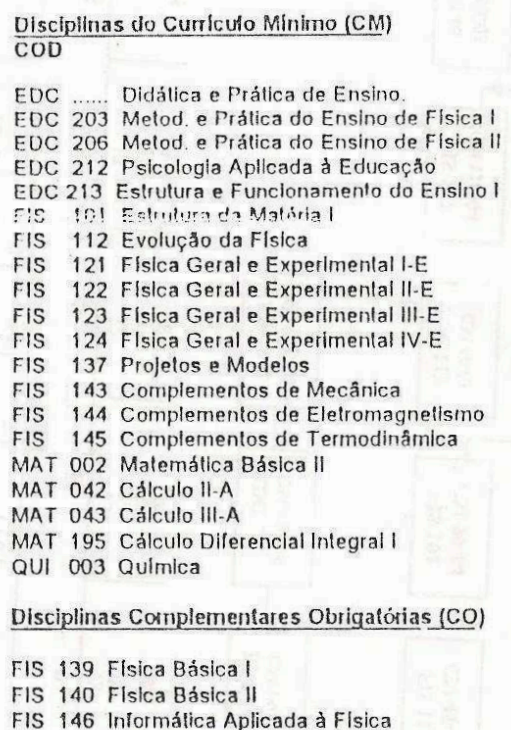

FIS 146 Informálica Aplicada à Fisica

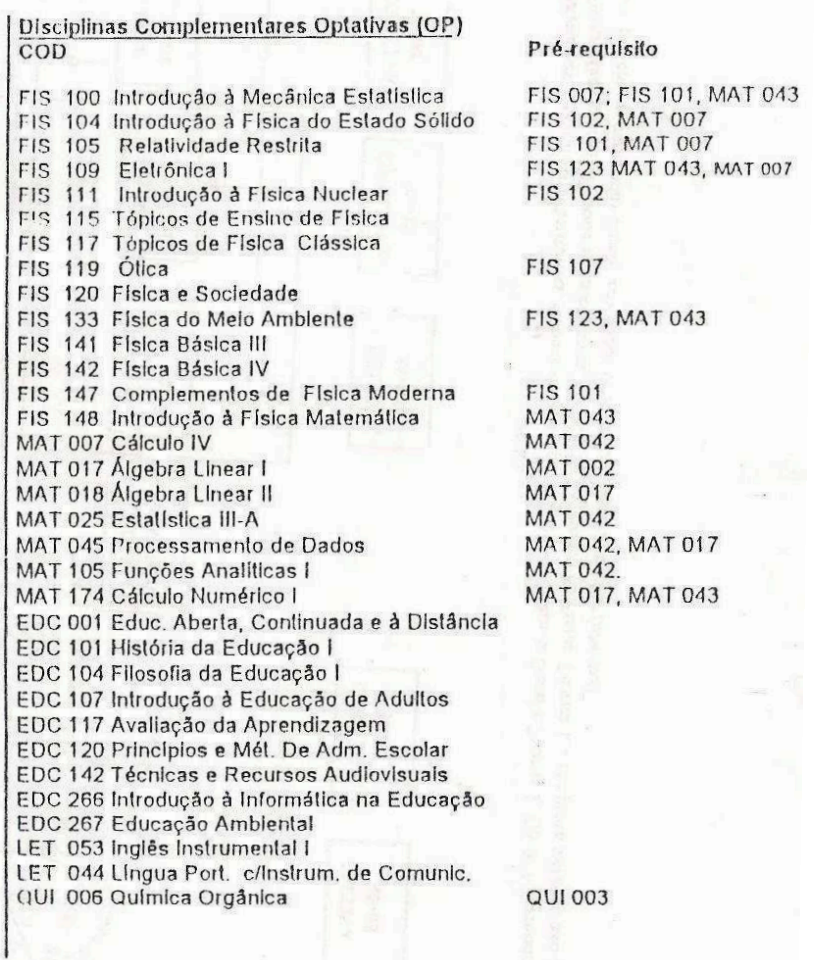

Fonte: Instituto de Física da UFBA, Colegiado de Graduação. Vide Rocha (2014). 
Anexo 2

Fluxograma das disciplinas do (novo) Curso de Física - Licenciatura, noturno, para alunos ingressos no ano de 1999

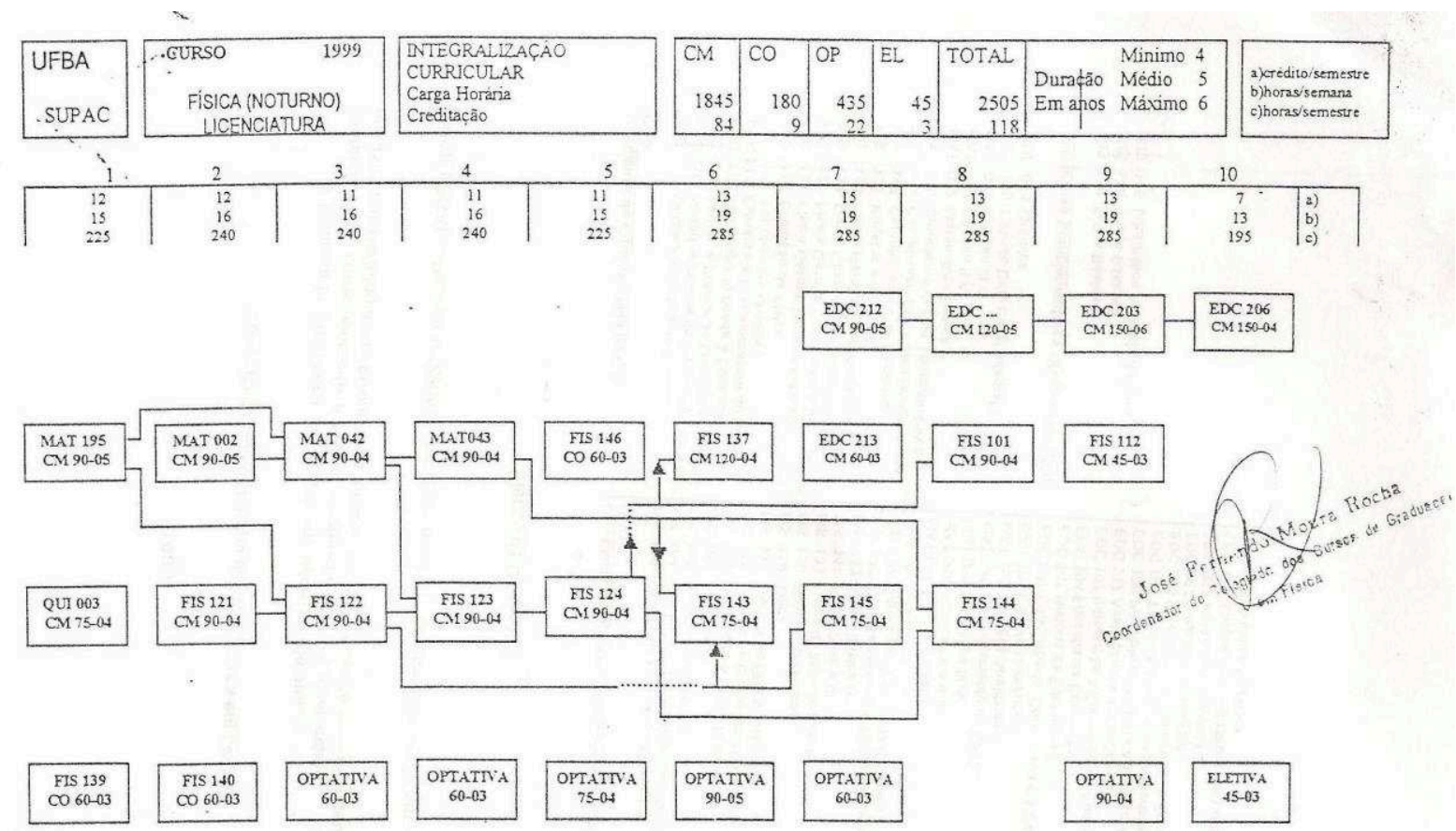

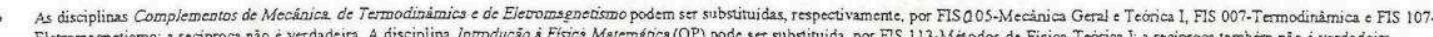
Eletromagnetismo; a seciproca náo e vetdaderra A disciplina hed

Fonte: Instituto de Física da UFBA, Colegiado de Graduação. Vide Rocha (2014). 